\title{
TELAAH REVOLUSI MENTAL DAN PENDIDIKAN KARAKTER DALAM PEMBENTUKKAN SUMBER DAYA MANUSIA INDONESIA YANG PANDAI DAN BERAKHLAK MULIA
}

\author{
Muhammad Kristiawan \\ Fakultas Keguruan dan Ilmu Pendidikan Universitas Muhammadiyah Sumatera Barat \\ Korespondensi: Luak Sarunai, Malana Ponco, Batusangkar, Sumatera Barat \\ e-mail: muhammad.kristiawan@yahoo.co.id
}

\begin{abstract}
Mental revolution and character education have an important role to advance human civilization. Essentially, the mental revolution and character education were aimed at making learners' smart and noble. If these goals are achieved, the human civilization will tend to be more advanced than before. Conversely, if both or one of those goals ruled out, it will appear the destruction of civilization. For Indonesia, to make the learners' smart and have moral required mental effort revolution integrated with a comprehensive character education. Mental revolution and character education are two aspects related and mutually aligned. Both of these provide relatively solutions to establish smart and noble Indonesian human resources.
\end{abstract}

Kata kunci: revolusi mental, pendidikan karakter, sumber daya manusia Indonesia yang pandai dan berakhlak mulia

\section{PENDAHULUAN}

$\mathrm{P}$

endidikan Indonesia saat ini menghadapi suatu paradoks yang menuntut respon dan keteladanan dari para pemimpin bangsa. Ada Ujian Nasional yang menakutkan, Kurikulum 2013 yang "setengah matang", gengster pelajar yang menyeramkan, bullying pelajar yang sadis, kekerasan siswa yang brutal, hingga pelecehan seksual dan begal.

Sudah banyak Undang-Undang, Peraturan Pemerintah, Permendiknas, Permen PAN dan RB, perdirjen yang dihasilkan, telah dibentuk sejumlah badan, komisi, badan, lembaga yang mengurus pendidikan. Otonomi daerah telah dilaksanakan dan telah diselenggarakan diklat, workshop, seminar untuk guru. Ada begitu banyak beasiswa dan bantuan pendidikan, ada dana BOS, BSM, DOS, dana CSR, dan lain-lain. Kesemuanya ditujukan dalam rangka perbaikan pengelolaan pendidikan yang demokratis dan akuntabel. Namun, sejumlah tradisi atau budaya yang tidak mendidik, mulai dari korupsi, kolusi, etos kerja rendah, intoleransi terhadap perbedaan, dan sifat kerakusan, sampai sifat ingin menang sendiri, kecenderungan menggunakan kekerasan dalam memecahkan masalah, pelecehan hukum, dan sifat oportunis, kesemuanya ini masih berlangsung, dan ini adalah hasil dari proses pendidikan kita (Suprapto, 2014: 1) dan (Ikhsan, 2014: 1). Oleh karena itu, sudah saatnya Indonesia melakukan tindakan korektif, tidak dengan menghentikan proses reformasi yang sudah berjalan, tetapi dengan 
mencanangkan revolusi mental, menciptakan paradigma, budaya pendidikan, dan pendekatan education building baru yang lebih manusiawi, sesuai dengan budaya nusantara, bersahaja, dan berkesinambungan.

Mazzola (2013) melakukan survei tentang bullying (tindak kekerasan) di sekolah. Hasil survei memperoleh temuan sebagai berikut (1) setiap hari sekitar 160.000 siswa mendapatkan tindakan bullying di sekolah, 1 dari 3 usia responden yang diteliti (siswa pada usia 18 tahun) pernah mendapat tindakan kekerasan, $75-80 \%$ siswa pernah mengamati tindak kekerasan, $15-35 \%$ siswa adalah korban kekerasan dari tindak kekerasan maya (cyber-bullying). Survei Mazzola kemudian didukung oleh Rigby (2009) yang mengungkapkan bahwa "these days bullying is accepted in many schools throughout the states; it is extremely damaging to the minority of students, mentally, emotionally, physically, and academically". Karakter negatif pada orang dewasa sering dilakukan secara tersembunyi sehingga hanya kalangan tertentu saja yang mengetahuinya. Dengan kemutakhiran teknologi informasi dan komputer sekarang ini, banyak terjadi karakter negatif di kalangan mahasiswa, antara lain: (1) menulis tugas makalah hanya mengunduh dari internet; (2) mereplikasi skripsi hasil karya orang lain; (3) menjawab soal ujian dengan bantuan HP yang dapat tersambung dengan internet. Jika karakter negatif ini dibiarkan, mahasiswa dikhawatirkan akan menurun kreativitasnya. Mahasiswa yang seperti ini akan menjadi pemalas, suka menempuh jalan pintas, tidak suka tantangan dan senang mencari sesuatu yang instan. Padahal di sisi lain, mahasiswa dituntut memiliki pribadi yang tangguh karena persaingan kerja semakin ketat.

Pembangunan karakter yang merupakan upaya perwujudan amanat Pancasila dan Pembukaan UUD 1945 dilatarbelakangi oleh realita permasalahan kebangsaan yang berkembang saat ini, seperti disorientasi dan belum dihayatinya nilai-nilai Pancasila; bergesernya nilai etika dalam kehidupan berbangsa dan bernegara; memudarnya kesadaran terhadap nilai-nilai budaya bangsa; ancaman disintegrasi bangsa; dan melemahnya kemandirian bangsa (Supinah dan Parmi, 2011: 1).

Untuk mendukung perwujudan cita-cita pembangunan karakter sebagaimana diamanatkan dalam Pancasila dan Pembukaan UUD 1945 serta mengatasi permasalahan kebangsaan saat ini, maka pemerintah menjadikan pembangunan karakter sebagai salah satu program prioritas pembangunan nasional. Pendidikan karakter ditempatkan sebagai landasan untuk mewujudkan visi pembangunan nasional, yaitu "mewujudkan masyarakat berakhlak mulia, bermoral, beretika, berbudaya, dan beradab berdasarkan falsafah Pancasila" (Supinah dan Parmi, 2011: 1-2).

Pembinaan karakter harus terus menerus dilakukan secara holistik dari semua lingkungan pendidikan yaitu keluarga, sekolah, dan masyarakat. Menurut Miftahudin (2010) pendidikan karakter pada usia dini di keluarga bertujuan untuk pembentukan, pada usia remaja di sekolah bertujuan untuk pengembangan sedangkan pada usia dewasa di bangku kuliah bertujuan untuk pemantapan. Tugas-tugas pendidik adalah menyediakan lingkungan belajar yang baik untuk membentuk, mengembangkan dan memantapkan karakter peserta didiknya.

Revolusi mental sama pentingnya dengan pendidikan karakter yang harus segera dilakukan, meski sangat sederhana, konsep yang ditawarkan Presiden Republik Indonesia Joko Widodo itu didasari oleh pemikiran yang sangat fundamental, filosofis, dan empiris sehingga mampu menyentuh akar persoalan. Sejak masa kampanye sampai sidang kabinet pertama, Presiden sudah jelas menyata- 
kan bahwa revolusi mental harus terjadi di Indonesia. Presiden Joko Widodo pernah menuliskan definisi revolusi mental sebagai "menciptakan paradigma, budaya politik, dan pendekatan nation building baru yang lebih manusiawi, sesuai dengan budaya Nusantara, bersahaja, dan berkesinambungan." Dalam penjabarannya ada 3 (tiga) dimensi dalam pembangunan manusia Indonesia, yaitu sehat, cerdas, dan berkepribadian. Kesemuanya untuk menuju manusia Indonesia yang berkepribadian (Biro Informasi dan Persidangan, 2014: 2).

Revolusi mental harus dimulai dari pendidikan, mengingat peran pendidikan sangat strategis dalam membentuk mental anak bangsa. Pengembangan kebudayaan maupun karakter bangsa diwujudkan melalui ranah pendidikan. Menurut Suprapto (2014) pendidikan pengembangan karakter adalah sebuah proses berkelanjutan dan tidak pernah berakhir (never ending process). Selama sebuah bangsa ada dan ingin tetap eksis, pendidikan karakter harus menjadi bagian terpadu dari pendidikan alih generasi.

Implementasi pendidikan karakter tidak harus dikaitkan dengan anggaran. Dibutuhkan komitmen dan integritas para pemangku kepentingan di bidang pendidikan untuk secara sungguh-sungguh menerapkan nilai-nilai kehidupan di setiap pembelajaran. Pendidikan karakter tidak sekadar mengajarkan mana yang benar dan mana yang salah, tetapi juga menanamkan kebiasaan (habituation) tentang hal mana yang baik. Dengan begitu, peserta didik menjadi paham (kognitif) tentang mana yang baik dan salah, mampu merasakan (afektif) nilai yang baik (loving the good/moral feeling), dan perilaku yang baik (moral action), dan biasa melakukan (psikomotor) (Suprapto, 2014). Jadi, pendidikan karakter erat kaitannya dengan habit (kebiasaan) yang dipraktikkan dan dilakukan.

Anak-anak tidak membutuhkan kurikulum, tetapi mereka membutuhkan kehidupan yang benar-benar mampu menghidupi mereka. Mereka belajar dari kehidupan nyata, sementara yang terjadi sekarang, banyak nilai atau ajaran yang sudah ada itu dikaburkan, ditutup-tutupi dengan kebohongan yang dikemas dalam sebuah ikon berupa iklan yang justru menyesatkan. Mestinya, revolusi mental menfokuskan pada pembangunan manusia melalui pendidikan. Sedangkan guru adalah aktor utama terwujudnya masyarakat terdidik. Sejarah dunia juga telah membuktikan bahwa guru merupakan pondasi bagi pembangunan bangsa. Jika guru solid maka bangsa kita akan semakin maju dan bersatu. Sehingga pembangunan karakter dapat dilaksanakan secara berkelanjutan. Seorang guru bukan hanya menjalankan proses pembelajaran semata, melainkan mampu membangun pola pikir sekaligus karakter positif siswanya, percuma mengajar tanpa bisa membuat siswa belajar, akhirnya siswa hanya bisa menjadi "follower" (Ikhsan, 2014).

Revolusi mental, dapat menghasilkan ketahanan pendidikan, Indonesia yang berdaulat dalam bidang pendidikan, Indonesia yang berkepribadian secara sosial budaya, pendidikan yang mengkaji potensi yang dimiliki Indonesia dengan sebuah sistem pendidikan yang akuntabel, bersih dari praktik korupsi yang bisa dirasakan oleh seluruh anak bangsa. Kemudian didukung oleh birokrasi yang bersih, andal, dan kapabel, yang benarbenar bekerja melayani kepentingan pendidikan dan mendukung pekerjaan guru untuk membentuk karakter siswa. Di sini, birokrat sebagai pelayan, bukan minta dilayani, birokrat tahu bentuk kondisi lapangan, melihat dengan "mata kepala sendiri, bukan hanya menerima 
laporan dari bawahan”. Revolusi mental sesungguhnya adalah sebuah gerakan ke dalam, yaitu perbaikan sikap diri sebagai individu, dan perbaikan evaluasi diri sistem yang sudah rusak karena korup, tidak adil, dan malah bertentangan dengan tujuan pendidikan nasional (Ikhsan, 2014: 1).

Revolusi mental memang harus diinisiasi dari proses pembelajaran dan secara simultan berjalan di bidang-bidang lainnya. Sekurangnya 18 tahun waktu anak Indonesia menghabiskan waktu di bangku pendidikan, mulai plalygroup hingga perguruan tinggi. Lembaga pendidikan menjadi "rumah kedua" untuk menempa anak-anak menjadi manusia dewasa yang bermartabat dan berkepribadian. Pastilah pendidikan sangat strategis dalam membentuk mental anak bangsa karena proses ini berkelanjutan dan tidak pernah berakhir (never ending process) dan di sinilah karakter anak mulai disemai.

\section{PEMBAHASAN}

\section{Model Pendidikan Karakter}

Pancasila dan Undang-Undang Dasar Negara Republik Indonesia Tahun 1945 memberikan landasan filosofis serta berbagai prinsip dasar dalam pembangunan pendidikan. Berdasarkan landasan filosofis tersebut, sistem pendidikan nasional menempatkan peserta didik sebagai makhluk yang diciptakan oleh Tuhan Yang Maha Esa dengan tugas memimpin kehidupan yang berharkat dan bermartabat serta menjadi manusia yang bermoral, berbudi luhur, dan berakhlak mulia yang menjunjung tinggi dan memegang teguh norma agama dan kemanusiaan untuk menjalani kehidupan sehari-hari, baik sebagai makhluk Tuhan, makhluk individu, maupun makhluk sosial (Adi, 2010: 5). Renstra Kemendiknas (2010-2014: 3) menyebutkan beberapa paradigma pendidikan menyangkut peserta didik, dua di antaranya menyangkut pemberdayaan manusia seutuhnya dan pembelajaran sepanjang hayat berpusat pada peserta didik.

Dari landasan filosofis Pancasila dan Undang-Undang Dasar 1945 kemudian ditambah Renstra Kemendiknas (2010-2014) tersebut jelas bahwa peserta didik butuh pendidikan karakter agar menjadi manusia seutuhnya. Menurut Dickinson (2009) pendidikan karakter adalah "the sum of continuously developing moral and ethical qualities and the demonstration of those qualities in people's emotional responses, thinking, reasoning, and behavior". Lebih lanjut Dickinson (2009) menyatakanbahwa pendidikan karakter "creates a meaningful framework and incorporates aspects of social-emotional learning, conflict resolution, violence prevention, social skills training, and service learning". Menurut Darmiyati (2009: 36) materi pendidikan karakter dapat dikelompokkan ke dalam tiga hal nilai moral atau nilai akhlak yaitu pertama, akhlak terhadap Tuhan yang Maha Esa, mengenal Tuhan sebagai pencipta dan sifat-sifat-Nya, dan meminta tolong kepadaNya. Kedua, akhlak terhadap diri sendiri, orang tua, orang yang lebih tua, teman sebaya, dan orang yang lebih muda. Ketiga, akhlak terhadap lingkungan (alam, baik flora maupun fauna dan sosial masyarakat). Pendidikan karakter seharusnya menjadi proses secara keseluruhan di dalam kelas, kegiatan ekstrakurikuler, proses bimbingan dan penghargaan semua aspek kehidupan. Contohnya pemberian tauladan dari orang dewasa untuk tidak korupsi, dermawan, menyayangi sesama makhluk Allah dan sebagainya (Rukiyati, 2013: 201).

Dalam buku Eleven Principles of Effective Character Education yang diterbitkan oleh Character.org (2014), pendidikan karakter "helps students to develop important human qualities such 
as justice, diligence, compassion, respect, and courage". Pendidikan karakter menurut Nur (2012) sejalan dengan empat pilar pendidikan yang dicanangkan oleh UNESCO (United Nations for Educational, Scientific, and Cultural Organization), yaitu pertama, learning to know atau belajar mengetahui; kedua, learning to do atau belajar bekerja; ketiga, learning to be atau belajar menjadi diri sendiri; keempat, learning to live together atau belajar hidup bersama. Pilar ketiga memiliki dampak implikasi pada metode belajar yang bersifat mandiri dan akan menjadi manusia yang akan bertangung jawab. Pilar keempat, belajar untuk toleransi terhadap orang lain termasuk berbagai macam perbedaan etnis, nilai-nilai dan agama yang berbeda. Pilar keempat seharusnya perlu diterapkan pada negara-negara yang sedang berkembang (Maryeni, 2013: 131).

Muhadjir (2003: 164) menawarkan alternatif pengembangan nilai moral yaitu melalui proses internalisasi. Nilainilai moral yang diaktualisasikan pada peserta didik. Di sisi yang lain peserta didik diberikan pemahaman betapa pentingnya kecerdasan emosional dan kecerdasan spritual lewat internalisasi atau menghayati nilai moral tersebut. Dikarenakan konsep keimanan dapat naik turun atau menipis, oleh karena itu sebuah keharusan dilakukan internalisasi baik secara rasional maupun lewat penghayatan.

Identitas pendidikan moralitas secara sosial memiliki hubungan untuk membangun kesadaran individu yang begitu mendalam. Peserta didik seharusnya dibimbing untuk memiliki kesadaran menjalin hubungan sosial secara harmonis melalui tingkah laku yang baik, berfikir positif kepada orang lain, memiliki rasa empati, suka menolong dan bertangung jawab, dan menghargai ber- bagai macam pendapat. Semua sifat seperti ini akan membantu peserta didik untuk hidup harmonis dalam lingkungan sosial yang dialaminya (Maksudin, 2013: 145). Dalam buku Eleven Principles of Effective Character Education (2014) terdapat sebelas prinsip dalam membangun peserta didik yang berkarakter antara lain "promotes core values; defines "character" to include thinking, feeling, and doing; uses a comprehensive approach; creates a caring community; Provides students with opportunities for moral action; offers a meaningful and challenging academic curriculum; fosters students' selfmotivation; engages staff as a learning community; fosters shared leadership; engages families and community members as partners; and assesses the culture and climate of the school".

Menurut Luneto (2014: 142) pendidikan karakter memiliki peran yang begitu berarti untuk menciptakan lingkungan yang lebih kondusif. Secara jelas arah kebijakan pembangunan nasional 2010-2014 adalah pada pembentukan akhlak mulia dan karakter bangsa. Terjadinya degradasi moral dan menurunnya nilai kebanggaan berbangsa dan bernegara dipandang sebagai gejala belum efektifnya implementasi pendidikan karakter. Di tengah kebangkrutan moral bangsa, maraknya tindak kekerasan, inkoherensi politisi atas retorika politik, dan perilaku keseharian pendidik. Dengan pendidikan karakter yang diterapkan secara sistematis dan berkelanjutan, peserta didik akan menjadi cerdas emosinya. Kecerdasan emosi ini adalah bekal penting bagi peserta didik dalam mempersiapkan masa depan, karena seseorang akan lebih mudah dan berhasil menghadapi segala macam tantangan kehidupan, termasuk tantangan untuk berhasil secara akademis. 
Sebenarnya, menurut Ikhsan (2014) Pusat Kurikulum Kemendikbud sudah menyusun strategi pendidikan karakter melalui pembelajaran (learning), keteladanan (modelling), penguatan (reinforcing) dan pembiasaan (habituating), dan menetapkan 18 nilai utama dalam pendidikan karakter yakni relijius, jujur, toleransi, disiplin, kerja keras, mandiri, demokratis, ingin tahu, semangat kebangsaan, cinta tanah air, menghargai prestasi, bersahabat/ komunikatif, cinta-damai, gemar membaca, peduli lingkungan, peduli sosial, dan tanggung jawab. Nilai utama pendidikan karakter tersebut didukung dengan teori Pearson \& Nicholson (2000) yang mengungkapkan bahwa nilai karakter adalah "honesty, respect, empathy, kindness, and caring play into affect with students who have relationships with classmates, teachers, friends, and family". Kemudian The Boston University School of Education (2002) menyarankan agar pendidikan karakter "may not be a major emphasis in many schools currently, but appears to be an unavoidable element which schools need to consider for future inclusion". Viadero (2003) mengungkapkan bahwa program pendidikan karakter "can be very useful in the sense of helping prevent school violence, drug problems, and promiscuous sexual activity". Menurut Otten (2000) pendidikan karakter "integrated into the school community is a strategy to help reengage our students, deal with conflict, keep students on task in the learning environment, and reinvest the community with active participation".

Hasil temuan Zuchdi (2006) pada semua jenjang pendidikan di Daerah Istimewa Yogyakarta juga menunjukkan bahwa (1) konteks institusional sekolah masih belum secara optimal mendukung pelaksanaan pendidikan karakter; (2) strategi indoktrinasi masih digunakan meskipun porsinya tidak terlalu besar, kadar pemberian teladan masih perlu ditambah, fasilitasi nilai yang sangat sesuai untuk melatih kemampuan membuat keputusan justru tidak banyak digunakan, pengembangan keterampilan hidup (soft skills) yang terkait dengan nilai dan moralitas juga belum maksimal; dan (3) iklim pendidikan karakter belum sepenuhnya kondusif. Beberapa saran yang diajukan antara lain (a) setiap lembaga pendidikan mulai dari Taman KanakKanak sampai Sekolah Menengah Atas, bahkan Perguruan Tinggi hendaknya memiliki program pendidikan karakter yang terintegrasi dengan semua bidang studi melalui kegiatan baik intra maupun ekstrakurikuler; dan (b) konteks intitusional sekolah dan iklim pembelajaran harus kondusif untuk pembentukan karakter.

Darmiyati dan Muhsinatun (2010) menyimpulkan bahwa model pendidikan karakter yang efektif adalah model yang menggunakan pendekatan komprehensif. Pendidikan karakter diintegrasikan ke dalam berbagai bidang studi. Metode dan strategi yang digunakan bervariasi yang sedapat mungkin mencakup inkulkasi/penanaman, keteladanan, fasilitasi nilai, dan pengembangan soft skills (antara lain berpikir kritis, kreatif, berkomunikasi efektif, dan dapat mengatasi masalah). Semua warga sekolah (pimpinan sekolah, guru, siswa, pegawai administrasi, bahkan penjaga sekolah serta pengelola warung sekolah) dan orang tua murid serta pemuka masyarakat perlu bekerja secara kolaboratif dalam melaksanakan program pendidikan karakter. Temuan Darmiyati dan Muhsinatun tersebut didukung oleh Tordei (2008) yang mengungkapkan bahwa "teaching good character is the responsibility of each and every member of our community. It is about recognizing and exemplifying positive character traits that both our children and we display. Children are our most valuable asset, they are our future. What 
we chose to invest in our children today is what our world of tomorrow will be". Tempat pelaksanaan pendidikan karakter adalah di dalam kelas maupun di luar kelas dalam berbagai kegiatan, termasuk kegiatan di rumah dan di dalam lingkungan masyarakat dengan melibatkan partisipasi orang tua.

Akbar (2008) meneliti tentang internalisasi nilai dan karakter peserta didik Daarut Tauhied Bandung. Hasil penelitian menunjukkan bahwa pendidikan dilaksanakan dengan menyeimbangkan antara aspek pikir dan dzikir (hati) dengan menggunakan metode learning by doing, simulasi, aksi sosial, khidmad dan ikhtiar, sosiodrama, studi lapangan, hikmah, dan evaluasi reflektif yang mementingkan kesadaran diri. Nilai-nilai dan karakter terinternalisasi secara efektif yang ditunjukkan dengan ciri-ciri santri dan alumni yaitu suka membantu orang lain, disiplin, kerja keras, optimis, percaya diri, bersih, santun dan murah senyum, berpikir positif, mandiri, sangat menghargai orang lain, kreatif inovatif, patut diteladani, dan islami.

Sejak karakter dimunculkan menjadi landasan utama pendidikan, model pendidikan pesantren menjadi perhatian banyak pihak. Hal ini disebabkan karena pola pendidikan di pesantren dipandang telah mampu membentuk manusia yang berkarakter lebih positif dibanding sekolah biasa. Selain model pendidikan pesantren Daarut-Tauhied Bandung, berikut ini juga dikaji model pendidikan karakter di pesantren Gontor. Menurut Zarkasyi (2010), pondok pesantren Gontor telah menerapkan pendidikan karakter melalui a) memberi keteladanan (uswah hasanah) dalam hal nilai-nilai keikhlasan, perjuangan, pengorbanan, kesungguhan, kesederhanaan, dan tanggung jawab; b) mengkondisikan hidup di lingkungan berasrama sehingga proses pembelajaran berlangsung terus menerus di bawah pengontrolan guru; c) memberi pengarahan nilai dan filosofi hidup; d) menugaskan supaya dapat hidup mandiri dengan cara mengurus dirinya sendiri, mengelola usaha, memimpin organisasi dan bermasyarakat; dan e) membiasakan hidup disiplin, taat beribadah dan taat terhadap peraturan pondok.

Kajian hasil-hasil penelitian pendidikan karakter pada usia anak-anak dan remaja yang telah dipaparkan menuai kesimpulan bahwa model pendidikan karater pada usia anak-anak diberikan untuk pembentukan karakter. Proses pembentukan dimulai dari pengenalan perilaku baik dan buruk dan pembiasaan perilaku baik dalam kehidupan sehari-hari. Pada usia pra sekolah, pendidikan karakter efektif dilakukan oleh keluarga. Oleh sebab itu, penting sekali bagi keluarga baru yang memiliki anak usia di bawah lima tahun untuk memberi lingkungan belajar yang terbaik di rumah. Orang tua harus meluangkan waktunya untuk mendidik anak-anak. Ibu yang bekerja di luar rumah tidak disarankan mempercayakan sepenuhnya pendidikan anak-anak usia dini kepada pembantu di rumah. Anak usia sekolah (6-12 tahun) sudah mulai memasuki lingkungan di luar rumahnya, anak akan lebih percaya dengan perkataan gurunya daripada orang tuanya sendiri. Pendidikan karakter anak usia Sekolah Dasar sangat efektif dilakukan di sekolah. Lingkungan sekolah (guru dan siswa) memiliki peran yang kuat dalam membentuk karakter anak.

Remaja masih berada dalam tahap pertumbuhan dan perkembangan. Remaja memiliki kepribadian yang masih labil dan sedang mencari jati diri untuk membentuk karakter permanen. Pendidikan pada usia remaja menjadi momen yang penting dalam menentukan karakter seseorang setelah dewasa. Lingkung- 
an pergaulan di sekolah maupun di rumah mempunyai peluang yang sama kuatnya dalam pengembangan karakter. Oleh sebab itu, perlu ada kerja sama dan komunikasi yang baik antara sekolah dan keluarga dalam mengembangkan karakter anak remaja.

Tugas-tugas pendidik pada usia remaja lebih kompleks daripada tugastugas pada usia anak-anak. Sesuai dengan karakteristik mental usia remaja yang sedang dalam tahap pencarian jati diri, tugas pendidik adalah menciptakan lingkungan yang sebaik-baiknya dengan memberikan banyak aktivitas positif supaya remaja tidak terjerumus pada kegiatan negatif yang merugikan masa depannya. Pendidikan karakter pada remaja dilakukan untuk pengendalian diri supaya remaja tidak terjerumus ke dalam karakter negatif. Supaya karakter positif dapat diinternalisasi menjadi karakter yang permanen, sekolah bertugas menyediakan banyak pilihan yang mendukung berkembangnya karakter positif tersebut dan menekan peluang munculnya karakter negatif. Model pendidikan karakter pada usia remaja dilakukan untuk menanamkan kedisiplinan, kejujuran, rasa hormat menghormati dan saling tolong menolong dalam semua kegiatan.

Pendidikan karakter perlu memperhatikan tahap-tahap belajar pada ranah afektif. Bloom (1964) membuat lima tahap belajar ranah afektif yaitu penerimaan, pemberian tanggapan, penghargaan, pengorganisasian dan internalisasi. Pada usia anak-anak, belajar afektif dapat dilakukan sampai tahap ke tiga yaitu tahap penghargaan. Pada usia remaja, belajar afektif dapat maju satu tahap lagi yaitu ke ranah pengorganisasian. Karakter pada orang dewasa sudah terbentuk sejak anak-anak dan remaja. Pendidikan karakter melalui model-model pembelajaran belum tentu efektif dilaksanakan. Pendidikan karakter orang dewasa yang sesuai adalah melalui peningkatan kesadaran untuk berperilaku positif dan evaluasi diri (self evaluation). Pendidikan karakter lebih efektif jika muncul dari kesadaran dirinya sendiri, bukan pengaruh dari orang lain. Bentuk-bentuk pendidikan karakter antara lain dilakukan melalui ceramah dan pengajian, pengangkatan tema pendidikan karakter dalam forum seminar, diskusi, media masa, film, penulisan karya ilmiah yang bertema pendidikan karakter, belajar dari pengalaman hidup orang lain, dan sebagainya. Banyak pengalaman orang-orang yang berkarakter negatif dapat berubah menjadi positif setelah mereka dihadapkan pada permasalahan hidup dan belajar dari kehidupan orang lain yang sedang mengalami masalah.

\section{Revolusi Mental Dimulai dari dalam Kelas}

Revolusi Mental menurut Daniel (2014) mengandung tiga tahap yang sederhana dan mudah untuk dipahami oleh semua orang yaitu "first, the awareness of the various problems that occurred in our life and the hope for a better future; second, the turning point process that denies or rejects all bad acts and inhumane ways of life; third, let God be the center of life so that our life becomes more humane". Kemudian Daniel (2014) juga menambahkan untuk melakukan revolusi mental cukup dengan "let God be the center of our life".

Salah satu gagasan menarik dari presiden terpilih Joko Widodo pada saat kampanye capres adalah akan dilakukannya "revolusi mental" jika terpilih. Di tengah carut-marutnya kondisi bangsa terutama maraknya korupsi di negara kita saat ini gagasan seperti itu cukup menyedot perhatian publik. Meskipun sebenarnya ini bukan gagasan baru. Karena, Bung Karno juga pernah menyampaikan gagasan yang sama pada 
pidato peringatan hari ulang tahun kemerdekaan Indonesia ke-11 tahun 1956.

Joko Widodo memfokuskan pada masalah berikut ini (Isa, 2014) "sudah saatnya Indonesia melakukan tindakan korektif, tidak dengan menghentikan proses reformasi yang sudah berjalan, tetapi dengan mencanangkan revolusi mental menciptakan paradigma, budaya politik, dan pendekatan nation building baru yang lebih manusiawi, sesuai dengan budaya Nusantara, bersahaja, dan berkesinambungan". Merrill dan Burrola (2015) juga mengungkapkan bahwa Presiden Joko Widodo sering mengungkapkan 'the country's need for a mental revolution a paradigm shift in thinking that the Indonesian people and government would need to make in order to achieve what he called a free, fair and prosperous Indonesia".

Joko Widodo sangat tegas dan eksplisit mengenai tujuan apa yang hendak dicapainya dan cara apa yang digunakan demi kemajuan dan perkembangan bangsa. Menurut Isa (2014) Presiden Joko Widodo menggunakan istilah "revolusi" tidak berlebihan. Sebab, Indonesia memerlukan suatu terobosan budaya politik untuk memberantas setuntas-tuntasnya segala praktik-praktik yang buruk yang sudah terlalu lama dibiarkan tumbuh kembang sejak zaman Orde Baru sampai sekarang. Revolusi mental beda dengan revolusi fisik karena ia tidak memerlukan pertumpahan darah. Namun, usaha ini tetap memerlukan dukungan moril dan spiritual serta komitmen dalam diri seorang pemimpin dan selayaknya setiap revolusi diperlukan pengorbanan oleh masyarakat.

Dalam melaksanakan revolusi mental, kita dapat menggunakan konsep Trisakti yang pernah diutarakan Bung Karno dalam pidatonya tahun 1963 dengan tiga pilarnya, "Indonesia yang berdaulat secara politik", "Indonesia yang mandiri secara ekonomi", dan "Indonesia yang berkepribadian secara sosial-budaya". Terus terang kita banyak mendapat masukan dari diskusi dengan berbagai tokoh nasional tentang relevansi dan kontektualisasi konsep Trisakti Bung Karno ini (Isa, 2014).

Revolusi mental bukan hanya menyangkut masalah mindset tapi lebih dari itu. Subaweh (2014) memaknai 'mental' sebagai nama bagi segala sesuatu yang menyangkut cara hidup cara berpikir, cara memandang masalah, cara merasa, cara mempercayai/ meyakini, cara berperilaku dan bertindak. Mental berkaitan erat dengan karakter dan budaya. Ketika mental dimaknai begitu luas maka revolusi mental harus membongkar budaya yang selama ini sudah tertanam kuat dan kini sebagian sudah hilang. Salah satu di antaranya adalah budaya malu. Akhir-akhir ini budaya malu sepertinya sudah tercabut dari akar budaya kita. Betapa banyak para pejabat yang tersandung kasus korupsi dengan cerianya ketika diwawancarai media. Sedikit pun tak tampak rasa bersalah, penyesalan atau malu (Subaweh 2014). Begitu juga cara hidup para pejabat dan para selebriti kita. Mereka adalah para panutan sekaligus idola. Pejabat dan selebriti menjadi trend setter di negeri ini. Betapa konsumtifnya mereka, rumah mewah dan mobil mewah bukan hanya yang mereka butuhkan sementara itu yang selalu disaksikan masyarakat lewat media elektronik setiap hari.

Menurut Kartadinata (2014) sekadar rasa malu pun sakarang menjadi sangat berharga dan sangat dirindukan bangsa Indonesia yang ingin menjadi bangsa berperadaban tinggi. Malu, saat ini tak ubahnya permata nan indah yang perlu digosok sehingga bernilai miliaran rupiah. Tanpa menggosok rasa malu melalui revolusi mental, bangsa ini akan tetap menjadi "batu koral", berserakan 
tak berharga. Korupsi, kolusi, nepotisme, bahkan kejahatan tradisional seperti mencuri, merampok, dan menipu dilakukan secara terang-terangan bahkan dijalankan secara bersama-sama. Kecintaan terhadap harta benda sangat dahsyat melebihi cintanya kepada kebenaran, bahkan melebihi cinta kepada Tuhan. Maka, jika kondisi Indonesia seperti ini dibiarkan, derajat bangsa Indonesia tidak akan pernah meningkat. Kita tetap menjadi negara berkembang, terpuruk, terbelakang, menjadi konsumen, dikerjain bangsa lain, dan selalu menjadi pecundang. Revolusi mental menjadi satusatunya jalan mengubah bangsa yang bermental budak nafsu menjadi bangsa berkarakter kuat, bermental baja, berderajat tinggi, dan taat terhadap Tuhan Yang Maha Esa.

Berhasilnya revolusi mental konon akan membuka pintu gerbang "Indonesia baru" di negara kita tercinta. Hanya, dari mana memulai pekerjaan maha besar itu. Revolusi mental pastilah tidak bisa dilakukan secara demilioratif apalagi instan. Mengubah karakter bangsa haruslah dipandang sebagai upaya untuk menanamkan sesuatu seluas bangsa dan untuk dimensi waktu yang jauh ke depan (Subaweh, 2014).

Masalah mentalitas bangsa adalah bagian dari masalah kultural (budaya). Oleh karena itu salah satu cara mengubahnya harus melalui cara kultural juga yakni melalui pendidikan. Dengan kata lain revolusi mental harus dimulai dari dalam kelas (Subaweh, 2014). Gurulah yang harus bercucuran keringat untuk pekerjaan besar itu, dan yang lebih penting lagi hanya guru yang berkarakter yang bisa menjadi garda depan (avant garde) revolusi mental itu.

Sejak beberapa tahun terakhir di sekolah sudah diajarkan pendidikan karakter bangsa. Ada 18 karakter yang dikembangkan, antara lain iman, takwa, berakhlak mulia, jujur, santun, toleran, mandiri, selalu ingin berprestasi, dan lain-lain. Masing-masing karakter diintegrasikan dalam setiap pembelajaran. Artinya kecemasan tentang menurunnya karakter bangsa sudah lama terdeteksi. Maraknya perkelahian pelajar, narkoba, pornografi, human trafficking adalah indikator-indikator yang sudah menggejala.

Dalam konteks revolusi mental yang paling aktual dan sedang heboh adalah implementasi Kurikulum 2013. Diterapkannya Kurikulum 2013 pada hakikatnya secara struktural dan sistematis dimulainya revolusi mental. Hanya pertanyaannya sekarang sudah menyadarikah para guru kita terhadap masalah ini. Jika guru tidak jeli dan hanya masalah pembelajaran tematik integratif dengan pendekatan saintifik (scientific approach) yang ditangkap maka dapat dipastikan revolusi mental akan gagal. Hal inilah barangkali yang perlu dicermati.

Membangun mental anak bangsa agar menjadi anak yang baik bukanlah hal yang mudah. Dalam konteks berbangsa dan bernegara membangun Indonesia baru yang nantinya Indonesia bebas korupsi haruslah dimulai dari mendidik anak-anak bangsa sejak dini. Artinya sejak SD, saat ini, anak harus sudah ditanamkan dan dibiasakan berbuat jujur.

Selama ini jujur lebih banyak hanya menjadi pengetahuan. Celakanya kadang masih ada standar ganda memaknai kejujuran. Sehingga ada sebagian masyarakat yang menganggap jujur sebagai mujur. Tetapi tidak sedikit yang berpikiran jujur itu kojur. Akibatnya kejujuran terabaikan dan perilaku yang muncul "mumpung ada kesempatan". Ini yang harus menjadi keprihatinan kita bersama (Subaweh, 2014).

Menurut Akhmaloka (2015) upaya untuk melakukan perbaikan mental apakah reformasi atau revolusi mental, perlu menyentuh dua faktor sekaligus yaitu cara berpikir serta lingkungan/tatanan 
sosial. Dalam perbaikan cara berpikir, kuncinya adalah bagaimana setiap orang belajar untuk makin mengenal dan menghargai keberadaan orang-orang lain. Di setiap tempat, di setiap ruang, kita tidak hidup sendirian. Kita hidup di tempat atau ruang itu bersama dengan orang-orang lain, dengan segala keanekaragaman yang ada pada mereka. Kita hidup dalam suatu ruang hidup bersama, dalam suatu keanekaragaman. Kehidupan bersama akan menjadi lebih baik kalau masing-masing mengenal dan menghargai perbedaan-perbedaan, dan menyikapi perbedaan-perbedaan secara adil. Cara berpikir demikian dapat dikembangkan, diajarkan dan dilatihkan di dalam kelas.

\section{PENUTUP}

Setiap peradaban betapapun primitifnya tentunya mempunyai kumpulan pengetahuan dari eksistensi akal sehat (common sense) yaitu pengetahuan yang diperoleh melalui pengalaman secara sengaja ataupun tidak disengaja yang bersifat sporadis dan kebetulan. Ilmu

\section{DAFTAR RUJUKAN}

Adi, Kuntor. 2010. Model Pendidikan Karakter di Universitas Sanata Dharma Yogyakarta. Yogyakarta: Sanata Dharma Press.

Akbar, Sa'adun. 2009. Pengembangan Model Pembelajaran Nilai dan Karakter Untuk Sekolah Dasar Berbasis Model Pendidikan Nilai dan Karakter Di Pesantren Daarut-Tauhied Bandung. e-jurnal Ilmu Pendidikan, Universitas Negeri Malang. diunduh tanggal 11 Desember 2010

Akhmaloka. 2015. Revolusi Mental dan Pendidikan Pascasarjana. mencoba untuk menafsirkan terutama fenomena alam dengan mencoba mencari penjelasan tentang berbagai kejadian terutama penjelasan yang bersifat postulasional yang tidak terlepas dari penafsiran yang bersifat rasional dan metafisis. Ilmu mempunyai kerangka penjelasan yang masuk akal yang mencerminkan kenyataan yang sebenarnya melalui penjelasan teoritis secara rasional dengan pembuktian yang dilakukan secara empiris. Adapun kesimpulan yang dapat ditarik dari pembahasan artikel ini adalah revolusi mental dan pendidikan karakter merupakan dua aspek yang terkait dan saling selaras. Kedua hal tersebut dapat memberikan pemecahan masalah yang relatif lebih tuntas dalam pembentukan pribadi sumber daya manusia Indonesia yang pandai dan berakhlak mulia. Revolusi mental dan pendidikan karakter dimulai dari dalam kelas sejak peserta didik memperoleh pendidikan. Jika revolusi mental dan pendidikan karakter berhasil terlaksana, maka terbukalah pintu gerbang "Indonesia baru".

Bandung: Sambutan Rektor ITB Pada Peresmian Penerimaan Mahasiswa Pascasarjana Baru Semester 2 Tahun Akademik 2014-2015.

Biro Informasi dan Persidangan. 2014. Jantung Revolusi Mental Presiden Joko Widodo ada di Kementerian Koordinator Pembangunan Manusia \& Kebudayaan. Jakarta: Menkokesra Siaran Pers Nomor: 34/Humas Kesra /X/2014

Bloom, Krathwohl \& Marsia. 1964. Taxonomy of Educational Objectives. New York: Longman 
Chacter.org. 2014. Eleven Principles of Effective Character Education. United State of America: www.character.org

Daniel, Agustinus. 2014. Mental Revolution a Small Change for a Better Civilization. SmashWordFREE Edition. Mental Revolution Global Network Indonesia.

Darmiyati, Zuchdi. 2009. Pendidikan Karakter: Grand Design dan Nilai-nilai Target. Yogyakarta: UNY Press.

Darmiyati, Zuhdan dan Muhsinatun. 2010. Pengembangan Model Pendidikan Karakter Terintegrasi Dalam Pembelajaran Bidang Studi Di Sekolah Dasar. e-jurnal Cakrawala Pendidikan Universitas Negeri Yogyakarta

Dickinson, Joan. 2009. Character Education Toolkit. South Carolina: Department of Education.

Ikhsan, Amri. 2014. Mengkonstruksi Revolusi Mental dalam Pendidikan. Jambi: jambiekspres. http://www.jambiekspres.co.id/beri ta-19248-mengkonstruksi-revolusimental-dalam-pendidikan.html

Isa, Ibrahim. 2014. Revolusi Mental, Revolusi Jokowi. Diskusi Bulanan Institut Peradaban 24 September 2014.

Kartadinata, Sunaryo. 2014. Menelisik Jargon Revolusi Mental. Bandung: Dimuat Halaman Utama Pikiran Rakyat Bandung, Selasa (28/8/2014).

Luneto, Buhari. 2014. Pendidikan Karakter Berbasis IQ, EQ, SQ. Jurnal Irfani, Volume. 10 Nomor 1, Juni 2014

Maksudin. 2013. Pendidikan Karakter Nondikotomik (Upaya Membangun Bangsa Indonesia Seutuhnya). Jur- nal Pendidikan Karakter Lembaga Pengembangan dan Penjaminan Mutu Pendidikan (LPMP) Tahun III, Nomor 2, Juni 2013.

Maryeni. 2013. Pendidikan Karakter dan Multikultural: Pilar-pilar Pendidikan dan Kebangsaan di Indonesia. Jurnal Kajian Pendidikan, Fakultas Sastera Universitas Negeri Malang 3(2) Desember 2013.

Mazzola, J. W. 2013. Bullying in School: a Strategic Solution. Washington, DC: Character Education Partnership

Merrill, David N. and Burrola, Bernard A. 2015. Indonesia's Mental Revolution. The Indonesian Journal of Leadership, Policy and World Affairs January-March 2015/Volume 5/Number 1.

Miftahudin. 2010. Implementasi pendidikan karakter di SMK Roudlotul Mubtadiin. Makalah disampaikan dalam seminar nasional: Strategi dan Implementasi Pendidikan Karakter Bangsa di Tingkat Satuan Pendidikan, Balitbang Kemendiknas, Tanggal 28-29 Agustus 2010 .

Muhadjir, Noeng. 2003. Ilmu Pendidikan dan Perubahan Sosial. Yogyakarta: Rake Sarasin.

Nur, Muhammad. 2012. Empat Pilar PendidikanMenurut UNESCO dan Lima Pilar Pendidikan di Indonesia.

http://nurs07.blogspot.com/2012/1 0/empat-pilar-pendidikan menurutunesco.html diakses 1 April 2015.

Otten, E. H. 2000. Character Education. Retrieved Apri12, 2008, from: www.indiana.edu/ ssdc/chardig.ht $\underline{\mathrm{m}}$

Pearson, Q., \& Nicholson, J. 2000. Comprehensive Character Edu- 
cation in the Elementary School: Strategies for Administrators, Teachers, and Counselors. Journal of Humanistic Counseling, Education \& Development, 38, 243. Retrieved April 8, 2008, from:

http://ezproxy.1ib.uwstout.edu

Renstra Kemendiknas 2010-2014.

Rigby, K. 2000. Bullying in School: Guidelines for Effective Action. Prqfessional Reading Guide for Educational Administrators, 21, 1. Retrieved January 7, 2009, from: www.kenrigby.netibguide2.htm

Rukiyati. 2013. Urgensi Pendidikan Karakter Holistik Komprehensif Di Indonesia. Jurnal Perndidikan karakter Edisi Juni 2013 Vol III. No. 3

Subaweh, Imam. 2014. Revolusi Mental itu Dimulai dari dalam Kelas. Probolinggo: Dinas Pendidikan http://pendidikan.probolinggokab.g o.id/revolusi-mental-itu-dimulaidari-dalam-kelas/

Supinah. dan Parmi, Ismu Tri. 2011. Pengembangan Pendidikan Budaya dan Karakter Bangsa melalui Pembelajaran Matematika di SD. Jakarta: Kementerian Pendidikan Nasional Badan Pengembangan Sumber Daya Manusia Pendidikan dan Penjaminan Mutu Pendidikan Pusat Pengembangan dan Pemberdayaan Pendidik dan Tenaga Kependidikan (PPPPTK) Matematika 2011.
Suprapto. 2014. Revolusi Mental Dimulai dari Pendidikan. Surabaya: Unika Darma Cendikia http://www.jawapos.com/baca/arti kel/6669/revolusi-mental-dimulaidari-pendidikan

The Boston University School of Education. 2002. Character Education: Creating a Positive Climate. Retrieved April 8, 2008, from:

www.boston.university.edu/equity/

Tordei, Elaine Pavloff. 2008. Finding Common Ground: Character Development in Ontario Schools. This publication is available on the Ministry of Education website at http://www.edu.gov.on.ca

Viadero, D. 2007. Proof of Positive Effects Found for Only a Few Character Programs. Education Week, 26 (42). Retrieved April 7, 2008, from:

www.edweek.orglew/articles/2007 /06/20/42character.h26.html

Zarkasyi, Abdullah Syukri. 2010. Pola Pendidikan Pesantren Dalam Pembentukan Karakter Bangsa. Makalah disajikan dalam seminar: Pendidikan Karakter Bangsa melalui Pola Pendidikan Pesantren. Balitbang, Kemendiknas, 10-12 Desember 2010, di Hotel Salak, Bogor.

Zuchdi, Darmiyati. 2006. Pendidikan Karakter Melalui Pengembangan Keterampilan Hidup dalam Kurikulum Persekolahan. Laporan Penelitian Hibah Pasca 2005-2006. Yogyakarta: Lembaga Penelitian UNY. 